\title{
Financial Literacy for Rural Resident: A Qualitative Study
}

\author{
$1^{\text {st }}$ Nur Anita Yunikawati \\ Economics Department \\ Universitas Negeri Malang \\ Malang, Indonesia \\ nur.anita.fe@um.ac.id \\ $4^{\text {th }}$ Marzanah A Jabbar \\ Economics Department \\ Universiti Putra Malaysia \\ Selangor, Malaysia \\ marzanah.fe@gmail.com
}

\author{
$2^{\text {nd }}$ Magistyo Purboyo Priambodo \\ Economics Department \\ Universitas Negeri Malang \\ Malang, Indonesia \\ magistyo.purboyo.fe@um.ac.id
}

$5^{\text {th }}$ Fatimah Sidi

Economics Department

Universiti Putra Malaysia

Selangor, Malaysia

fatimah.fe@gmail.com

\author{
$3^{\text {rd }}$ Emma Yunika Puspasari \\ Economics Department \\ Universitas Negeri Malang \\ Malang, Indonesia \\ emma.yunika.fe@um.ac.id
}

\begin{abstract}
The level of financial literacy has influenced several personal financial decisions. However, the level of financial literacy in rural communities is quite low. The development of personal curriculum plays a role in increasing the basic knowledge of finance so that it will also affect the rationality of a person to use his money. The first step is to analyze what they need. The purpose of this study is to describe the knowledge, attitudes, and financial behavior of rural communities to provide curriculum solutions that are appropriate for their own personal financial education. The method used in this study is a qualitative approach using semistructured interviews that are used to explore the knowledge, attitudes and behavior of rural communities in managing finances. Interviews have been conducted together with eleven informants, the number consisting of 6 men and 5 women. The eleven speakers come from different educational backgrounds and have different livelihoods. The results of this study are analyzing the personal finances of sources, knowledge and financial management, and financial planning in the future. Based on these results it can be concluded that the financial literacy of the people of Junrejo village is very low so that the people of Junrejo village hope to be able to take part in financial training. Therefore, it is expected that intervention from all parties is needed to improve financial literacy.
\end{abstract}

\section{Keywords-financial, literacy, rural, residents, qualitative}

\section{INTRODUCTION}

Financial literacy is one of the important things in the current era of the Industrial Revolution. Each individual is required to master the basic financial capabilities to make a personal financial plan [1]. Financial literacy or commonly referred to as financial literacy has many definitions. Financial literacy as the ability to read, analyze, manage, and communicate about personal financial conditions that affect material well-being. Financial literacy includes the ability to see financial choices, discuss money and financial problems without (or despite) inconvenience, plan for the future and respond competently to life events that affect daily financial decisions, including events in the general economy. Financial literacy is the knowledge one has about financial instruments. Financial literacy can be interpreted as financial knowledge that has the aim of achieving prosperity [2]. Financial literacy shows a financial understanding of general knowledge of finance, investment, savings, and insurance [3].

Various surveys show that Indonesia has a low financial level. One of them was a survey from OJK in 2014. The survey results showed that Indonesian people have high knowledge of savings financial products, which is $98.2 \%$. Public knowledge of high savings products is not balanced by the large percentage of the number of people who use these products. People who use savings products are only $50.8 \%$. The percentage of knowledge and use of pawnshop products is the smallest percentage, which is $0.9 \%$ (knowledge) and $0.0 \%$ (usage).

Various surveys or studies have been conducted to determine the level of financial literacy of the Indonesian people. One of them is the 2013 MasterCard financial literacy study of sixteen Asia Pacific countries in 2013. The survey results show that Indonesia's financial literacy level is ranked 14 (fourteen) out of a total of 16 (sixteen) countries. This explains that the Indonesian people's knowledge of the financial system is under other developing countries in Asia such as Malaysia and Vietnam. [4] stated that Indonesia is in the group of countries that have the lowest financial understanding.

The purpose of this study is to explore the financial literacy of Junrejo residents, describe the knowledge, attitudes and financial behavior of rural communities to provide curriculum solutions that are appropriate for their own personal financial education.

\section{METHOD}

\section{A. Study Design}

Qualitative research conducted comprised observation, focus groups and one-to-one semi-structured interviews whit participants within collaborative Particapatory Action Research (PAR). We have chosen a qualitative approach using semi-structured interviews for exploratory data gathering of residents information and attitudes in the field of personal finance [5]. This approach was chosen to allow the exploration of unforeseen issues, thus maintaining a baseline study rate for the target areas. Such qualitative data were associated with the mixed methods instrument development model to allow further analysis of this issue [6]. 


\section{B. Measurement}

Three researchers, based on existing research, several years of experience with personal finances (NAY and MPP), and the experience with semi-structured interviews (MYP) have iteratively developed the interview method. This is the interview instrument. The aim was to encourage a flexible and open assessment in five areas: education debt, pension scheme, savings, disability insurance and living insurance; and to provide a comprehensive assessment of financial knowledge, skills and concerns [7]. These target areas are common themes in existing literature and the knowledge of instrument designers; they have been included in the instrument to ensure that all residents comment on each of these areas. The reliability of the response system was developed through the instrument pilot with non-study group residents. The modifications and piloting continued until the system allowed for the required flow and communication depth to be facilitated. Three piloting rounds and overhauls have been completed [8]

\section{Data Collection}

We determine participants based on the results of our pretest. pretest was given to 40 participants and from that number we recruited 11 participants to attend the Focus Group Discussion (FGD). The 11 participants consisted of 6 men and 5 women who came from the Junrejo District, Junrejo District, Batu City. Participants have different characteristics both sex, age, income level, and type of livelihood [9]. We communicated with participants, in-depth interviews and FGDs conducted during July-September.

Data collection carried out by the location-based researcher consisted of three stages: stage 1 (month 1-2) participant observation using pretest to observe financial literacy scale; stage 2 (month 3-4) focus groups and stage 3 (month 5) semi-structured interviews [10].

\section{Data Analysis}

The researchers first carried out informal thematic analyzes when they wrote field notes consisting of a chronicle of descriptive rather than quantitative activities both observed and supplied as the ' raw material for study ' by coresearchers. The transcription notes system was used to define key points related to the research question [11]. This preliminary analysis showed the focus group issues in more detail. After the first round of focus groups, the author and colleagues read all the notes in a word document frequently and looked for common topics and issues. During the interviews, concept interpretation of the findings of the focus group were discussed in detail. All interviews have been recorded and transcribed to get to know the information and to start coding. All the specifics in the transcripts (e.g., sighs, laughter, silences and tears) are written down, because the omission could have changed their significance [12]. In order to produce coding-relevant concepts, transcriptions are uploaded to NVivo11. The word frequency question of NVivo made it easy to scan for keywords grouped under the same theme (in comprise less stem mots and synonyms). A full analysis of the data was provided in the text search query. The study was completed by an examination of themes after information had been coded in initial themes.

\section{RESULT}

Results from the focus group have been analyzed with a thematic analysis (NVivo11). Findings show that all participants were consistent in the way they were. All participants showed that their financial literacy rate was still low. During the FGD the researcher revoked all opinions expressed by the participants. We provide coding on each question that we give to 11 participants to present their demographic circumstances (such as gender, education level, and occupation)

As the central entrance of Batu City which is located at the east gate of the city, Junrejo District has a vital strategic role. Although the area of the Junrejo sub-district is not as large as the other two sub-districts, the role of this sub-district cannot be ignored, especially considering its position as a liaison with the Malang and surrounding areas.

Referring to the potential data of Junrejo Subdistrict, the geographical location of villages and the topography of the entire area of Junrejo Subdistrict including the slope / hill area (dominant slope). The total area of the Junrejo sub-district is around $25.65 \mathrm{~km} 2$ or around 12.88 percent of the total area of Batu City. As a hilly topographical area, Junrejo Subdistrict has access to Malang City and Malang Regency, so there are many artificial tourist attractions sprung up like Jatim Park 3 and Predator so that it can move the wheels of the economy in Junrejo District

\section{1) Daily Finances}

Statements on earnings included feelings of satisfaction with their work ("we're fortunate to have job security"). Nevertheless, the limited cash balance available on the residents salary was a major concern:

"I manage my money into different posts, which are current needs and needs or savings"

While other participants gave different comments. Several other residents gave different comments about their finances and uncertain cash flows. They rely on the added consideration of working time or a home business.

"My job isn't permanent, so I am worried about spending my money because my money just goes on tomorrow morning to buy rice"

\section{2) Spending}

Citing budgetary weisheit and practices early on, the residents were comfortable with their budgetary ability; many mentioned:

"I learned not to waste too much from a young age"

"I've got little cash and I keep a close eye on it"

Comments on sparingness were popular as well:

"My main philosophy is to try and spend as little as I can"

Although several residents commented on frugality, comments on the rationale for spending were also noted, despite the financial circumstances:

"It's challenging because we're at the end of a very long learning and development road. I want a bit too much to enjoy life. [I'm] taking a bit of a break from me now on"

\section{3) Saving}

Comments on savings and emergency funds, including, suggested residents with minimal reserves: 
"Didn't got anything like a protection fund".

As explained in the previous section, several stages of this PAR activity consist of planning, action, observation and reflection with the following detailed explanation.

\section{A. Assistance Planning}

Planning in the PAR program was prepared in a participatory manner with residents of Junrejo. In the determination phase of the program the researcher conducted the first FGD which was conducted in the first week of July. This FGD aims to get information about what programs are needed by the residents. In addition, to the FGD, a survey of the needs of the community was also carried out so that this activity was expected according to the needs. Planning is done by mapping or mapping and prioritizing potential activities to be developed in community empowerment programs.

Resident especially those who have middle income and lower tend to choose basic financial training because they feel that the financial basis is important for making financial planning. In accordance with the interests of the citizens, the researcher redeems with stakeholders so that the value for empowerment reaches maximum and satisfying results. The activities formulated through the process of mapping and discussing the preparation of action plans are:

\section{1) Basic financial training and financial instruments}

\section{2) Digital economy training}

\section{B. Implementation of Assistance Activities}

Through this cycle of activities it is hoped that the people of Junrejo will be able to use technology to support their economy, in addition to growing awareness of the importance of managing household finances. Based on the priority choices of the types of activities above, the implementation of these activities is carried out periodically.

\section{1) First cycle: Basic Financial Training}

Basic Financial Training with the theme "Financial Literacy in the Disruptive Era" which was attended by around 11 participants from the Junrejo Urban Village residents. The researcher's expectation of providing basic financial training is that the higher the financial literacy of citizens, the more it will have an impact on the citizens' economy both for skills improvement and financial change. In this first cycle it is divided into 2 days (7-8 August 2019). The first day of the first cycle discussed basic personal finance. The speaker on the first cycle and the first day was Nur Anita Yunikawati, M.Pd giving an introduction to the discussion by describing basic personal finance such as calculating simple interest, compound interest, inflation, opportunity cost, time value, asset liquidity and so forth.

Activities in the first cycle began with opening and greeting from stakeholders of the Junrejo Village. After the opening and welcoming ceremony, the program continued with holding a basic financial knowledge pretest. Then proceed with the presentation of material, question and answer and post-test.

Based on the results of the achievements, it is known that most residents have a moderate level of financial literacy. This is because residents come from different backgrounds. This pretest consists of 5 questions related to general financial knowledge.

After the presentation of material by Nur Anita Yunikawati, M.Pd, a question and answer session was opened relating to general financial knowledge. After the questions and answers the team provided assistance to residents regarding the management of personal finances for their household. And the event closed with a post-test. Some of the interviews with the participants, they are very happy with this kind of activity because they add knowledge about personal financial management that can be applied in everyday life.

"Apparently there are many kinds of insurance, sir, I think only BPJS. I have BPJS insurance, but yes, it is because of coercion from the Lurah. He said if I did not join BPJS I would later be difficult to get services from the Village ". (BD, 48 years old)

\section{2) Second Cycle}

The second cycle is divided into two days, 11-12 September 2019 at the Heritage Foundation. In the second cycle this is still in the form of an action program carried out by the researcher. This second cycle of action program focuses on using the internet to support the economy of the people of Junrejo. Based on observations and observations it is known that most of the residents who take part in our program are MSMEs engaged in supporting tourism in Kota Batu and Kelurahan Junrejo in particular. Some of them have the livelihood of café owners, hotel owners, as tour guides, innkeepers, restaurant owners and so on. However, their activities are still traditional, not utilizing the maximum technology and inferior to similar entrepreneurs who have large capital. So that researchers are interested in providing material about the use of the internet to improve the economy of citizens.

Speakers in the second cycle of the first day were Magistyo Purboyo Priambodo, Nur Anita Yunikawati, and Emma Yunika Puspasari. These three speakers explained for 2 consecutive days about the use of the internet and explained the practical use of the internet based on the needs of each participant. With this the participants are asked to create an account to be able to register at OYO or reddoors. So for conventional lodging owners to compete in this digital erra. As many as 8 residents are MSMEs engaged in conventional lodging. Through discussions with them, residents were really surprised by the ease of the internet being taught by the speakers. They feel there is new knowledge to market their services and profit calculation. The reflections generated from the second cycle are:

a) Residents can create an Oyo account and so on

b) Citizens can make interesting advertisements

c) Residents can create a business IG account to introduce their business

d) And the use of other startups.

\section{3) Third Cycle}

This third cycle was carried out on 8-9 October 2019. The focus of the action on this third cycle was the use of financial technology. That in the world of SMEs capital is important for the progress of his business. However, it is not uncommon for citizens to be more inclined to have credit to loan sharks. This makes the economy of citizens who have middle income and below cannot survive with their business conditions. Therefore, researchers are interested in providing solutions so that citizens can have capital but with easy conditions.

Speakers in this third cycle are Nur Anita Yunikawati, Emma Yunika Puspasari, and Magistyo Purboyo Priambodo. Before explaining the material the researchers reviewed and made a reflection of the results of the second cycle, namely the use of the internet. Some residents find it helpful to create 
Oyo and reddors accounts. Because with the application they easily get customers. In addition they can by marketing products in the form of services to customers. So they believe that their income rises because of the account.

\section{CONCLUSION}

Based on the research that has been done, it can be concluded that the financial literacy of the Junrejo Village community is being due to coming from various educational backgrounds and livelihood backgrounds. The study used a participatory action research (PAR) approach consisting of cycle 1 , skulus 2 , cycle 3 , and cycle 4 . From the four cycles it succeeded in changing the mindset of participants and changing citizens' financial decisions wisely by making financial planning.

\section{ACKNOWLEDGMENT}

I would like to express my special thanks to my rector and also the chairperson of LPPM, who gave me the golden opportunity to do this wonderful project, which also helped me in doing a lot of research and I came to know about so many new things and I am really thankful to them.

\section{REFERENCES}

[1] S. Agarwal, G. Amromin, I. Ben-David, S. Chomsisengphet, and D. D. Evanoff, "Financial literacy and financial planning: Evidence from India," Journal of Housing Economics, vol. 27, pp. 4-21, 2015.

[2] L. Arrondel, M. Debbich, and F. Savignac, "Financial literacy and financial planning in France," Numeracy, vol. 6, no. 2, p. 8, 2013.

[3] A. Lusardi, and O.S. Mitchell, "Financial literacy and retirement preparedness: evidence and implications for financial education," Business Economics, vol. 42, no. 1, 2007.

[4] Atkinson, and F. Messy, "Measuring Financial Literacy: Results of the International Network on financial education," OECD Working Papers on Finance Insurance and Private Pensions, no. 15, 2012.

[5] B. S. Thapa, and S. R. Nepal, "Financial literacy in Nepal: a survey analysis from college students," NRB Economic Review, vol. 27, no. $1,2015$.

[6] J. P. Bharucha, "Determinants of Financial Literacy Among Indian Youth," Dynamic Perspectives on Globalization and Sustainable Business in Asia, IGI Global, pp. 154-167, 2019.

[7] F. Demir, and F. Temizel, "Financial Literacy of University Students: A Case Study for Anadolu University," Int. Journal of Management Economics and Business, vol. 11, no. 24, 2015.

[8] N. S. Mahdzan, and S. Tabiani, "The Impact of Financial Literacy on Individual Saving: an Exploratory Study in the Malaysian Context," Transformationss in Business and Economics, vol. 12, no. 1, pp. 4155, 2013.

[9] M. H. Ahsan "Financial literacy research on undergraduate students in Malaysia: current literature and research opportunities," International Journal of Education and Research, vol. 1, no. 11, 2013.

[10] Morgan, J. Peter, and Q. Long, "Determinants and impacts of financial literacy in Cambodia and Vietnam," ADBI Working Paper Series, no. 754, 2017.

[11] D. L. Remund, "Financial literacy explicated: The case for a clearer definition in an increasingly complex economy," Journal of consumer affairs," vol. 44, no. 2, pp. 276-295, 2010.

[12] G. D. Willows, "Actual and Self-Assessed Financial Literacy among Employees of a South African University," Numeracy, vol. 12, no. 1, p. 11, 2019. 